\title{
Fungal Deterioration of Used and Unused Synthetic Crankcase Oils
}

\author{
Anwuli Uche Osadebe*, Chukwuemeka Ezenwa Ifenwanta, Gideon Chijioke Okpokwasili \\ Department of Microbiology, University of Port Harcourt, Choba, Nigeria \\ Email address: \\ anwuli.osadebe@gmail.com (A. U. Osadebe) \\ ${ }^{*}$ Corresponding author \\ To cite this article: \\ Anwuli Uche Osadebe, Chukwuemeka Ezenwa Ifenwanta, Gideon Chijioke Okpokwasili. Fungal Deterioration of Used and Unused \\ Synthetic Crankcase Oils. Frontiers in Environmental Microbiology. Vol. 4, No. 1, 2018, pp. 11-15. doi: 10.11648/j.fem.20180401.12
}

Received: December 25, 2017; Accepted: January 16, 2018; Published: February 2, 2018

\begin{abstract}
Crankcase oils are essential to the smooth running of any engine. Like most hydrocarbon derivatives, their composition leaves them susceptible to attack by biodeteriogens especially fungi. Furthermore, these oils are disposed of indiscriminately inadvertently ending up in soil and sometimes groundwater. The biodeterioration of used and unused synthetic crankcase oils by fungi was studied in order to facilitate better management of spoilage both prior to use and within the engine and to pinpoint possible remediative agents. Used samples consisted of oils that had been in use within car engines for four months or more while unused samples were bought from the local store. The crankcase oils studied were Lenoil GTX SAE 15W/40, Lenoil GLX SAE 20W/50 and National X-100 SAE 40. Isolation from the oil samples was done using Potato Dextrose agar via the pour plate technique while mineral salt agar containing the test oil as the sole carbon source was used to assess fungal utilisers. The accumulated fungal biomass was determined following a 30 day incubation period. The fungi found to contaminate and grow in synthetic crankcase oils were Aspergillus niger, Aspergillus flavus, Fusarium sporotrichioides and Trichoderma harzianum. Each organism had a different growth pattern and the same organism grew at different rates on different oil samples over the same period. National X-100 SAE 40 oil fared better overall than Lenoil GTX SAE 15 W/40 and Lenoil GLX SAE 20W/50 being the least susceptible to fungal utilisation. Used oil types was more prone to fungal attack than the unused oils. Fusarium sporotrichioides dominated in used oil samples while Aspergillus niger dominated in unused samples. Used oil samples showed both greater counts and greater biomass accumulation compared to the unused samples. This study showed that fungi are capable of contaminating and deteriorating synthetic crankcase oils. The use of antifungal agents is recommended to combat their activities where unwanted. These fungi could also be used extensively in the bioremediation of soil contaminated with crankcase oils.
\end{abstract}

Keywords: Biodeterioration, Bioremediation, Crankcase Oil, Fungi, Lubricant, Pollution

\section{Introduction}

Motor oils are hydrocarbon products whose main function is lubrication. These oils must be viscous enough to maintain a lubricant film under operating conditions but should be as fluid as possible to remove heat and avoid power loss due to viscous drag. They should also be stable under thermal and oxidative stress, have low volatility and possess some ability to control friction and wear [1]. The activities of organisms in in-use oils often interfere with these properties and thus, the performance of such oils. Oils being moist media which retain water and form emulsions readily, facilitate the growth of organisms that have a predilection for moist environments which leads to their deterioration and spoilage. This is so because wherever organic matter is in contact with water, in the absence of effective natural and man-made preservatives, it is anticipated that microorganisms will colonise this environment. Different oil formulations are susceptible to different strains or mixtures of strains of microorganisms [2]. Normally, once the oil is contaminated, biodeterioration is likely to continue until positive anti-microbial measures are taken. Biodegradation is an uneven process with some components of the oil selectively degraded and others persisting. The activities of microorganisms in in-use lubricating oil often result in emulsion instability, drop in $\mathrm{pH}$, increased corrosiveness, depletion of functionality, 
accumulation of slime and sludge amongst other changes [3].

The increase in population across the globe translates to more car owners which prompts increased demand, production, usage and eventual disposal of engine oils; this is especially true in developing countries where mass transportation is somewhat limited [4]. Irregular power supply and the consequent increase in the use of power generators have further exacerbated this problem. There is little or no regulation on the disposal of engine oil in developing countries where the chosen method of disposal, is often empting of these oils from the car engines onto the ground from where the oils then find their way into drainage, waterways and ground water [5-7]. This illegal dumping of used motor oil is an environmental menace with global implications [8]. Akochere et al. [9] reported the discharge of used oils from vehicles as a major cause of soil pollution in Buea, Cameroon. Similar observations were made in Gwagwalada, Nigeria and Pudukkottai region, India [10], [11]. Increased demand for derivatives of petroleum including motor oils has led to a marked increase in soil contamination worldwide [12]. Used motor oil contains heavy metals and heavy polycyclic aromatic hydrocarbons known to contribute to mutagenicity, carcinogenicity, liver or kidney disease and bone marrow damage [11], [13]. Research has shown statistically significant impact of engine oil contaminated soils on plants including reduction in height and protein levels and loss of chlorophyll [14-15].

There is a need to understand not only the fate of crankcase oils prior to use or in the car engine but within the environment as well and the possible bioremediation potential of autochthonous microorganisms. The mitigation of environmental issues such as pollution using cutting-edge microbial biotechnology is a rapidly growing field [16]. Fungi are found in virtually every environment. They can act as mycofilters in the environment [17]. Several studies have highlighted the role of fungi in the deterioration of lubricating oils [18], [11]. Bioremediation using fungi often leads to complete degradation of petroleum hydrocarbon contaminants in soil often better than achieved with bacteria [19-21]. Fungi are known to synthesise enzymes capable of degrading high molecular weight complexes or more recalcitrant compounds [16].

The aim of this study is to gain an insight into the fungi involved in the biodeterioration of crankcase oils not only with a view to their management but to highlight possible bioremediative agents when these oils are discharged into the environment.

\section{Materials and Methods}

\subsection{Sample Collection}

Used oil samples were obtained as a "clean catch" into sterile bottles from the crankcases of cars that had been driven with the oils for four (4) months while the unused types were bought directly from the store. The oils tested were Lenoil GTX synthetic motor oil SAE 15W/40, Lenoil GTX synthetic motor oil SAE $20 \mathrm{~W} / 50$ and National oil X100 SAE 40.

\subsection{Isolation of Fungi}

Isolation was done using the pour plate technique. Fungi were isolated using sterile Potato Dextrose Agar (PDA) into which $50 \mu \mathrm{g} / \mathrm{ml}$ streptomycin had been incorporated to prevent bacterial growth. A two-fold serial dilution was carried out for each oil sample using molten PDA as the diluent. Samples of $0.2 \mathrm{ml}$ of the test oils were added to $19.8 \mathrm{ml}$ of PDA (in a warm water bath to prevent solidification) and then serially diluted after thorough mixing. Different dilutions were then plated and incubated at room temperature for 5 days. Following sub-culturing, the isolates were identified and characterised according to Larone [22] and Hunter and Bennett [23].

\subsection{Determination of Yield}

Mineral Salt Broth ( $\mathrm{pH} 7.2)$ with composition, $\mathrm{NaCl}$ : $10.0 \mathrm{~g}, \mathrm{MgSO}_{4} .7 \mathrm{H}_{2} \mathrm{O}: 0.42 \mathrm{~g}, \mathrm{KCl}: 0.29 \mathrm{~g}, \mathrm{KH}_{2} \mathrm{PO}_{4}: 0.83 \mathrm{~g}$, $\mathrm{NaHPO}_{4}: 1.25 \mathrm{~g}, \mathrm{NaNO}_{3}: 0.42 \mathrm{~g}$ and de-ionised water: $1 \mathrm{~L}$ was used [24]. A $0.1 \mathrm{ml}$ quantity of the lubricating oil sample was added to $100 \mathrm{ml}$ of the medium in an Erlenmeyer flask, fungi were isolated from each set up. The set up was then sterilised and inoculated with the organism (s) isolated from the particular oil sample being considered. Incubation was done in triplicate. Each set up had a fourth flask - the control - which remained uninoculated. The flasks were incubated at room temperature for 30 days. The dry weight of the fungal isolates determined the yield. The dry weight was ascertained by harvesting each organism from the flask using a filter paper of known weight to catch both mycelia and spores and then oven drying till a steady weight was reached.

\section{Results and Discussion}

The identities of the species are shown in Table 1. The genera include Aspergillus, Trichoderma and Fusarium. Figure 1 shows their distribution across the oil samples. These results are in consonance with reports that demonstrated the ability of Aspergillus niger, Aspergillus flavus, Aspergillus versicolor, Synecephalastrum, Trichoderma, Rhizopus, Neurospora, Mucor and Talaromyces to utilise and degrade spent and unspent engine oil and other hydrocarbon derivatives [25], [26]. The preponderance of Aspergillus sp. in engine lubricating oils has been shown by several studies [11], [27 - 29]. Another study further identified Trichoderma in addition to species of Aspergillus [16]. Fusarium sp., Trichoderma viridae, Aspergillus niger and other fungi were isolated from simulated displaced tanks [30]. Udochukwu et al. [28] as well identified Fusarium sp. as a utiliser of engine oils. 
Table 1. Fungal Isolates from the Synthetic Lubricating Oil Samples.

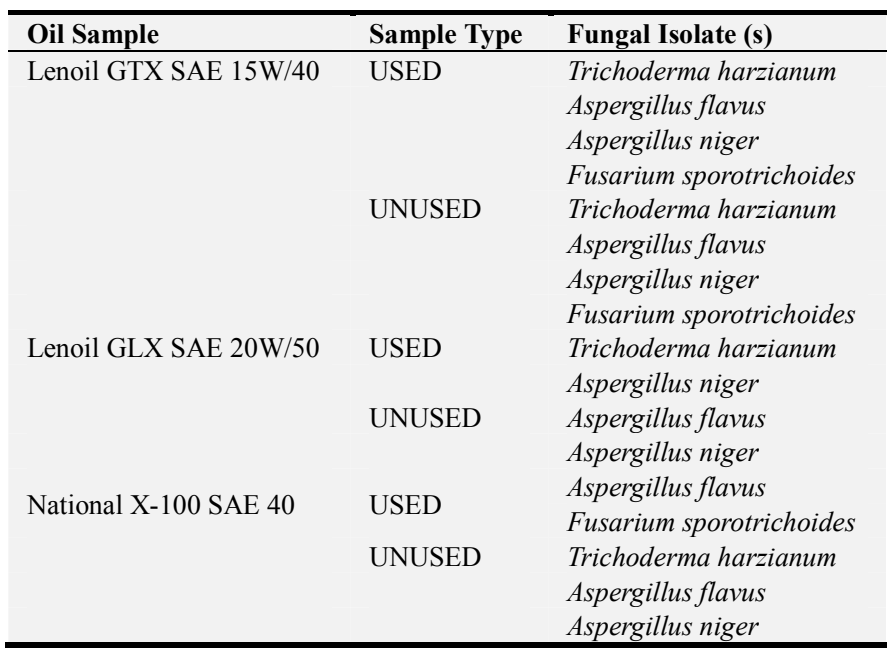

The results of the screen test for the utilisation of the various crankcase oil samples as sole carbon sources by fungi isolated from them show that all the organisms grew on the lubricating oil samples indicating that they used the oil as a raw material for growth. Lenoil GLX SAE 20W/50 supported the least fungal growth. Of all the isolates, only Trichoderma harzianum and Aspergillus niger were able to grow on used samples of Lenoil GLX SAE 20W/50 while unused samples of the oil were utilised solely by the two species of Aspergillus isolated. Fusarium sporotrichioidea

\section{USED OIL}

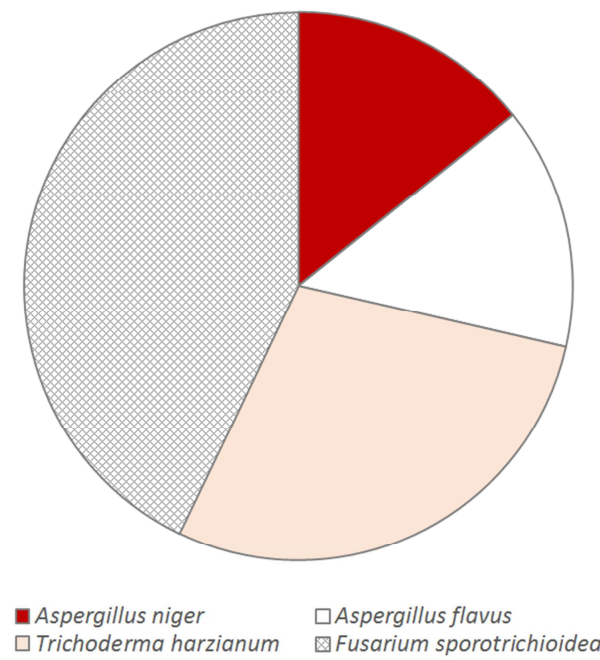

showed no growth at all on Lenoil GLX SAE 20W/50. Lenoil GTX SAE $15 \mathrm{~W} / 40$ seemed to be the most readily utilised as all the isolates were able to utilise both its used and unused samples. Fusarium sporotrichioidea grew best on used samples of Lenoil GTX SAE $15 \mathrm{~W} / 40$ while Trichoderma harzianum dominated in unused samples of the oil. For National X-100 SAE 40, Fusarium sporotrichioidea did not grow on unused samples while Trichoderma harzianum showed no growth on used samples of the oil. As highlighted in Figure 1, Fusarium sporotrichioidea and Trichoderma harzianum generally dominated across the used oil samples while Aspergillus niger and Aspergillus flavus dominated in the unused samples. This finding differs from the conclusions of a previous study that Aspergillus niger and Aspergillus flavus are the most efficient degraders of used engine oil [18]. Based on Figure 2, used oils on the average, had higher counts which is agreement with previous findings while studying microbial degradation potentials on motor engine lubricants [27]. This greater utilisation is somewhat expected as the used oils are not only in contact with water within the car engine but also tend to have higher heavy metal and have been subjected to wear by the engine. The highest fungal counts were observed in used samples of Lenoil GTX SAE 15W/40 and unused samples of Lenoil GLX SAE 20W/50. The lowest counts were observed across National X-100 SAE 40 samples.

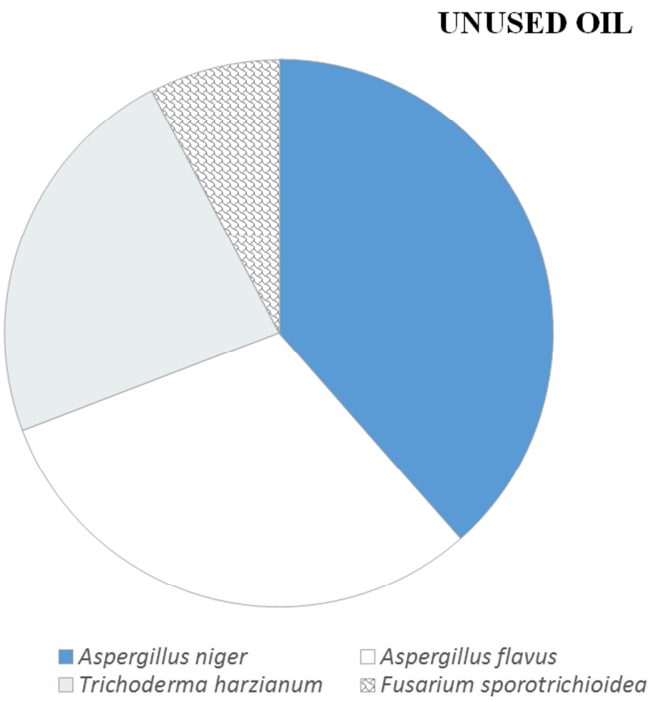

Figure 1. Distribution of the Isolates across Used and Unused Oil Samples.

It is important to point out here that the organisms grew only in those flasks where the oil formed a mat at its base. The rates of growth were slow and differed from one sample to the next, as is observed by the rates of appearance of the mycelia on the oil surface. The fact that the fungal isolates grew on the oil signifies that they are oil utilisers. Since the microorganisms can live in hydrocarbon fuel systems for a long period without an increase in growth, a distinction is drawn between fuel utilisers and fuel isolates [31]. Furthermore, it has been shown that not all the contaminating bacteria in lubricating oils had biodeterioration potential [27]. The growth of these fungal species in this work indicate that they are biodeteriogens and not merely contaminants. The results of the fungal biomass accumulated over 30days are illustrated in Figure 3. The fungal species grew at different rates on different oil samples as is seen by the differing dry weights. Even the same species grew at different rates in different oil samples. These variations could be attributed to the differences in the compositional, physical and chemical characteristics of the various oil formulations. Amongst these 
characteristics are structural configuration of the constituent hydrocarbons such as methyl branching, the type of infecting microbial species, type of oil and the prevailing environmental conditions [32]. Additionally, physical state of the oil viz. relative solubility in water, temperature and nutrient and oxygen availability play a role here. Similarly, co-oxidation has been found to be necessary for accomplishing significant biodeterioration of individual components of the oil [33]. Figures 2 and 3 further show that the growth of the fungal species on the used and unused types of oil differed. Used oil supported more fungal growth than unused oil. This result is in agreement with other reports [27], [33]. While in service, some components of the used oil are altered or lost, thereby making it more conducive for fungal utilisation when compared to unused oils. The unused oils could also be said to be somewhat sterile and any initial fungal load could be from handling and storage. Moreover, the presence of biocides and other preservatives may prove inhibitory to microbial growth [31]. These preservatives could be denatured when these oils are in an active motor engine. In addition, the physical and chemical changes which occur while the oil is in use may exert pressures which are selective for different dominant organisms at different times. Extremes of temperature and oxidation of oil components that occur in the engine change oil viscosity, result in a drop in $\mathrm{pH}$ in used oils and cause thermal stress, thereby encouraging the growth of microorganisms especially fungi in the oil.

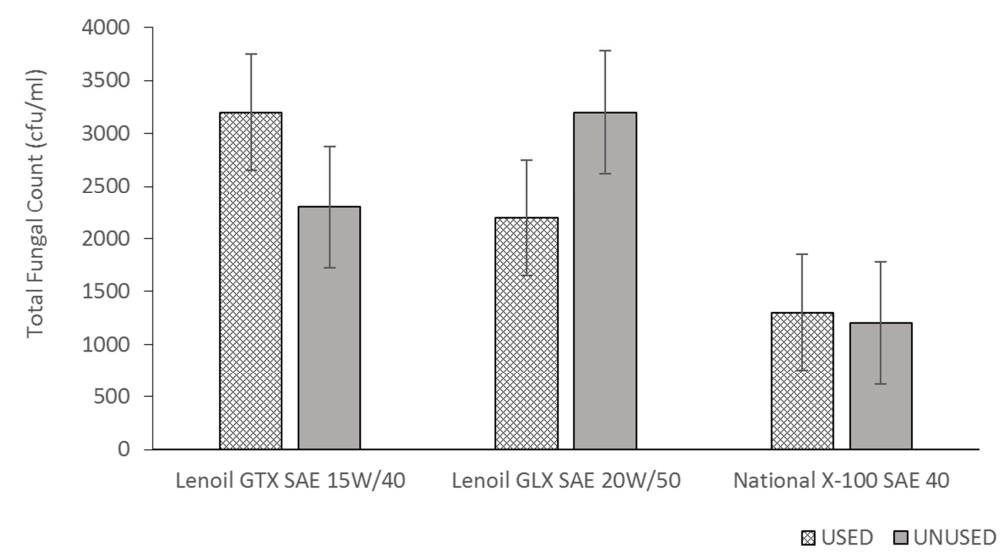

Figure 2. Mean Fungal Population of Crankcase Oil Samples after a 5-day Incubation period at Room Temperature.

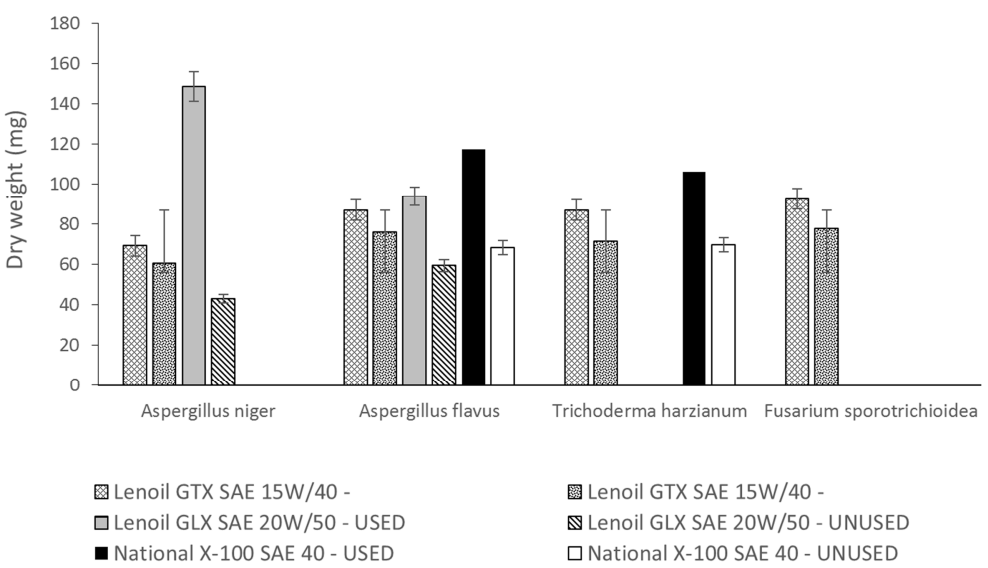

(Values are means of triplicates with Standard Deviation by the calculated confidence limits at 95\%)

Figure 3. Mean Dry weight of Fungal Isolates Grown on the Different Lubricating Oil Samples at Room Temperature for 30 days.

\section{Conclusion}

This study shows that fungi, Aspergillus niger, Aspergillus flavus, Fusarium sporotrichioides and Trichoderma harzianum are capable of contaminating and deteriorating synthetic crankcase oils. The use of antifungal agents is recommended to combat their unwanted activities. Different fungal species have different biodegradative potentials on lubricating oils. Following further research, these isolates obtained could be introduced into contaminated land to support enhanced bioremediation of soils impacted with waste engine oil.

\section{References}

[1] Menezes, P. L., Reeves, C. J. and Lovell, M. R. (2013) Fundamentals of Lubrication. Chapter 10 In: Lovell, M. R., Menezes, P. L., Ingole, S. P. and Nosonovsky, M. (eds.) Tribiology for Scientists and Engineers: From Basics to Advanced Concepts. Springer Science, New York, USA.

[2] Salam, L. B. (2016) Metabolism of waste engine oil by Pseudomonas species. 3 Biotech. 6 (1): 98. 
[3] Genner, G. and Hill, E. C. (1981) Fuels and oils In: Rose, A. H. (ed.) Economic Microbiology vol. 6. Microbial Deterioration. Academic Press, London. pp 259-306.

[4] Ismail, H. Y., Ijah, U. J. J., Riskuwa, M. L. and Allamin, I. I. (2014) Biodegradation of spent engine oil by bacteria isolated from the rhizosphere of legumes grown in contaminated soil. International Journal of Environment 3 (2): 63-75.

[5] Umanu, G. and Dodo, D. S. (2013) Assessment of oil-eating fungi isolated from spent engine oil polluted soil environments. The Pacific Journal of Science and Technology 14 (2): 609-616.

[6] Odjegba, V. J. and Sadiq, A. (2000) Effects of spent engine oil on the growth parameters, chlorophyll and protein level of Amaranthus hybridus L. Nigerian Journal of Basic and Applied Science 7: 1-46.

[7] Obayori, O. S., Salam, L. B. and Ogunwumi, O. S. (2014) Biodegradation of fresh and used engine oil by Pseudomonas aeruginosa LP5. Bioremediation and Biodegradation 5 (1): 1000213.

[8] Blodgett, W. C. (2001) Water soluble mutagens produced during the bioremediation of oil contaminated soil. Florida Scientist. 60 (1): 28-36.

[9] Akochere, J. F., Akanji, T. N., Yongabi, F. N., Nkwelang, G. and Ndip, R. N. (2008) Lubricating oil degrading bacteria in soil from filling stations and auto-mechanic workshops in Buea, Cameroun. Occurrence and characteristics of isolates. African Journal of Biotechnology 7: 170-176.

[10] Ugoh, S. C. and Moneke, L. U. (2011) Isolation of bacteria from engine oil contaminated soils in auto-mechanic workshops in Gwagwalada, Abuja, Nigeria. Academia Arena 3 (5): 28-33.

[11] Thenmozhi, R., Nagasathya, A. and Thajuddin, N. (2011) Studies on biodegradation of used engine oil by consortium cultures. Advances in Environmental Biology 5: 1051-1057.

[12] Alizera, H. and Asli, D. E. (2011) Response of seed germination and seedling growth of safflower and corn to gasoline and diesel fuel mixture. Advances in Environmental Biology 5 (1): 81-86.

[13] Abioye, O. P., Agamuthu, P. and Abdulaziz, A. R. (2012) Biodegradation of used motor oil in soil using organic waste amendments. Biotechnology Research International 2012, Article ID: 587041.

[14] Oluwole, O. S., Makinde, S. C. O. and Philips, D. A. (2005) The impact of spent engine oil pollution on the growth of Celosia argentea. Proceedings of the $4^{\text {th }}$ Faculty of Science Annual Conference, Lagos State University (LASU), Ojo, September $11^{\text {th }}-14^{\text {th }} \cdot$ pp68-72.

[15] Amund, O. O. and Adebiyi, A. G. (1991) Effect of viscosity on the biodegradability of automotive lubricating oils. Tribiology International 24 (4): 2235-2237.

[16] Sebiomo, A., Awosanya, A. O. and Awofodu, A. D. (2011) Utilisation of crude oil and gasoline by ten bacterial and five fungal isolates. Journal of Microbiology and Antimicrobials 3 (3): $55-63$.

[17] Makut, M. D., Ogbonna, A. I., Ogbonna, C. I. C. and Owuna, M. H. (2014) Utilisation of petroleum products by fungi isolated from the soil environment of Keffi metropolis, Nasarawa State, Nigeria. International Journal of Science and
Nature 5 (2): 14-19.

[18] Shahida, A. A., Sambo, S. and Salau, I. A. (2015) Biodegradation of used engine oil by fungi isolated from mechanic workshop soils in Sokoto metropolis, Nigeria. Sky Journal of Soil Science and Environmental Management 4 (6): 64-69.

[19] Thomas, S A. (2000) Mushrooms: Higher macrofungi to clean up the environment. Batelle International Issues, Fall 2000.

[20] Bento, F. M., Camargo, F. A. D. O., Okeke, B. C. and Frankenberger, W. T. (2005) Diversity of biosurfactant producing microorganisms isolated from soils contaminated with diesel oil. Microbiology Research 160: 249-255.

[21] Achal, V., Kumari, D. and Pan, X. (2011) Bioremediation of chromium contaminated soil by brown-rot fungus, Gloephyllum sepiarium. Research in Microbiology 6: 166-171.

[22] Larone, D. H. (1976) Medically important fungi: A guide to identification. Harper and Row, Hagerstown, MD. pp3-25.

[23] Hunter, B. B. and Bennett, H. L. (1973) Deuteromycetes (Fungi imperfecti.) In: Laskin, A. I. and Lechevalier, H. A. (eds.) CRC Handbook of Microbiology Vol. 1, Organismic Microbiology. CRC Press, Cleveland, Ohio. PP 405-433.

[24] Mills, A. L. and Breuil, C. and Colwell, R. R. (1978) Enumeration of petroleum degrading marine and estuarine microorganisms by the most probable number method. Can. J. Microbiol. 24: 552-557.

[25] George-Okafor, U., Tasie, F. and Muotoe-Okafor, F. (2009) Hydrocarbon degradation potentials of indigenous fungal isolates from petroleum contaminated soils. Journal of Physical and Natural Sciences 3 (1): 1-6.

[26] Adekunle, A. A. and Adebambo, O. A. (2007) Petroleum Hydrocarbon Utilisation by Fungi Isolated from Detarium senegalese (J. F. Gmelin) Seeds. Journal of American Science 3 (1): 69-76.

[27] Okpokwasili, G. C. and Okorie, B. B. (1988) Biodeterioration potentials of microorganisms isolated from car engine lubricating oil. Tribiology International 21: 215-220.

[28] Udochukwu, U., Omoghie, E. M., Chikezie, C. C. and Udinyiwe, O. C. (2017) Mineralisation of diesel-base engine oil by fungi isolated from selected workshops in Benin city, Nigeria. International Journal of Pharmaceutical Science Invention 3 (8): 1-5.

[29] Okerentugba, P. O. and Ezeronye, O. U. (2003) Petroleum degrading potentials of single and mixed microbial cultures isolated from rivers and refinery effluents in Nigeria. African Journal of Biotechnology 2 (9): 293-295.

[30] Bruce, N. (1982) A laboratory study of microbial growth in simulated fuel tanks. International Biodeterioration 18 (3): 87-91.

[31] Okpokwasili, G. C. and Williams, T. O. (1990) Stability to biodeterioration of vegetable oils. Serv. Agric. And Environ. Sci. 52-62.

[32] Schaeffer, T. L.; Cantwell, S. G.; Brown, J. L.; Watt, D. S. and Fall, R. R. (1979) Microbial growth on hydrocarbons: Terminal branching inhibits biodegradation. Applied Environmental Microbiology 38: 742-746.

[33] Atlas, R. M. (1981) Microbial degradation of Petroleum Hydrocarbons. An Environmental Perspective. Microbiology Review 45: 180-208. 